\title{
Primary Cutaneous Anaplastic Large Cell Lymphoma (pcALCL) in the Elderly and the Importance of Sport Activity Training
}

\author{
Antonello Sica ${ }^{1, *,+}$, Paola Vitiello ${ }^{2,+}$, Andrea Ronchi ${ }^{3, \dagger}{ }^{\dagger}$, Beniamino Casale ${ }^{4} \oplus$, \\ Armando Calogero ${ }^{5}$, Evangelista Sagnelli ${ }^{3}$, Gilca Costa Nachtigal ${ }^{6}$, Teresa Troiani ${ }^{1}$, \\ Renato Franco $^{3}$, Giuseppe Argenziano ${ }^{2}$ (D), Elvira Moscarella ${ }^{2}$ and Caterina Sagnelli ${ }^{3,+}+(\mathbb{D})$ \\ 1 Department of Precision Medicine, University of Campania Luigi Vanvitelli, 80131 Naples, Italy; \\ teresa.troiani@unicampania.it \\ 2 Dermatology Unit, University of Campania Luigi Vanvitelli, 80131 Naples, Italy; \\ paoladermosun@gmail.com (P.V.); giuseppe.argenziano@unicampania.it (G.A.); \\ elvira.moscarella@unicampania.it (E.M.) \\ 3 Department of Mental Health and Preventive, University of Campania Luigi Vanvitelli, 80131 Naples, Italy; \\ ronchi.andrea@hotmail.it (A.R.); evangelista.sagnelli@unicampania.it (E.S.); \\ renato.franco@unicampania.it (R.F.); sagnelli.caterina@libero.it (C.S.) \\ 4 Department of Pneumology and Tisiology, AO Dei Colli-V. Monaldi, 80130 Naples, Italy; \\ bennycasale@hotmail.com \\ 5 Department of Advanced Biomedical Sciences, University of Naples Federico II, 80131 Naples, Italy; \\ armando.calogero2@unina.it \\ 6 Department of Clinical Medicine, Faculty of Medicine at UFPel-Federal University of Pelotas, 1160 Centro, \\ Pelotas, Brazil; gilca.cn@gmail.com \\ * Correspondence: antonellosica@gmail.com; Tel.: +39-333-225-3315; +39-0811-957-3375 \\ + These authors contributed equally to the work.
}

Received: 25 December 2019; Accepted: 22 January 2020; Published: 29 January 2020

check for updates

\begin{abstract}
Primary cutaneous anaplastic large cell lymphoma (pcALCL) is part of a spectrum of cutaneous CD30+ lymphoproliferative disease that also includes lymphomatoid papulosis. It often occurs in elderly patients, presenting at a median age of 60 years, although it may occur at any age. It is a CD30+ T-cell neoplasm composed of large cells with anaplastic, pleomorphic, or immunoblastic morphology, with exclusively cutaneous onset and localization. The clinical course of pcALCL is predominantly indolent. Most elderly patients with lymphoma tend to have a sedentary lifestyle, which has a negative effect on their quality of life $(\mathrm{QoL})$ and survival. Several studies indicate that exercise has a positive impact on QoL because it reduces peak oxygen consumption, improves physical capacity, increases self-esteem, reduces accumulated stress, and promotes relaxation. Therefore, particularly in indolent lymphomas, it is necessary to indicate a program of physical activity to be practiced systematically. Complete surgical excision and local radiotherapy are the first line gold standard in pcALCL with a solitary lesion.
\end{abstract}

Keywords: cutaneous lymphoma in the elderly; skin tumors; T-cell lymphomas; sport activity training

\section{Introduction}

Primary cutaneous anaplastic large cell lymphoma (pcALCL) is a CD30+ T-cell neoplasm composed of large cells with anaplastic, pleomorphic, or immunoblastic morphology, with exclusively cutaneous onset and localization [1]. The clinical course of pcALCL is predominantly indolent, completely different from that of the systemic forms of anaplastic large cell lymphomas (ALCL) [2]. ALCL are a group of T-cell lymphoproliferative diseases characterized by the presence of anaplastic cells with 
CD30 positivity and a variable expression of T-cell markers [3]. Neoplastic cells defined as "hallmark cells" are morphologically distinguishable as large pleomorphic cells with abundant cytoplasm and eccentric kidney-shaped nuclei. These are common aspects of all kinds of ALCL, but each type differs in clinical presentation, prognosis, and molecular features. According to the most recent revision of the WHO (2016) [4], ALCL are classified as anaplastic lymphoma kinase ALK-positive large cell anaplastic lymphoma (ALK+ ALCL), ALK-negative ALCL (ALK- ALCL), breast-implant-associated ALCL (BI-ALCL), or pcALCL. The first two forms have a systemic clinical presentation and development with lymphadenomegaly, splenomegaly, hepatomegaly, and secondary extranodal infiltration mainly involving the skin, bones, soft tissues, and lungs, and are associated with systemic symptoms such as fever, weight loss, and night sweats. Central nervous system involvement is rare. At the onset of illness, it is common to find an already widespread disease in stage III-IV with systemic symptoms, according to the Ann Arbor staging system. ALK+ ALCL is more common in adolescents and children. ALK- ALCL has a higher incidence in adults over 60 years. Both forms are aggressive, with ALK+ ALCL in young people being responsive to chemotherapy and showing an approximate $70 \%$ long-term survival, while ALK- ALCL, usually seen in older adults, has a less favorable prognosis. Systemic ALK- ALCL with rearrangement in the DUSP22-IRF4 locus have a more favorable prognosis, while those with TP53 rearrangements have a poor prognosis.

BI-ALCL is a form localized in areas adjacent to the breast implant. It generally has an indolent course and a good prognosis. Morphologically comparable to the other forms, it is ALK- with an excellent response to surgical therapy. However, systemic development of this type is also known to occur, characterized by an unfavorable prognosis similarly to the above-described systemic forms.

Patients with pcALCL are frequently diagnosed at an older age, but it may also present in young people. Males are more often affected than females (a ratio of 3:1).

About $25 \%$ of patients have the DUSP22-IR4 locus at onset, while TP63 rearrangements are rare. Unlike systemic forms, these chromosomal aberrations do not appear to be related to a worse prognosis [5].

Support in patients with lymphoma is essential to avoid depression, reduction of self-esteem, and the onset of unreal emphasis of symptoms such as fatigue and pain [6,7]. It is striking how most cancer patients have a sedentary lifestyle, which can have a negative effect on their quality of life (QoL) [8,9]. In addition, several studies indicate that physical activity has a positive impact on QoL in cancer survivors [10,11], because it reduces peak oxygen consumption, improves physical capacity, increases self-esteem, reduces accumulated stress, and promotes relaxation [12]. Physical activity also exerts a favorable effect on metabolism, inflammation, and the immune system [13]. In particular, it regulates macrophages and the natural killer lymphocytes that are widely involved in interactions with cancer cells [14-16]. In addition, randomized studies have highlighted how physical activity in cancer patients may improve QoL [17-19]. In our department, we encourage patients to progressively increase and take part in a program of physical activity depending on their physical abilities and attitudes. Such physical activity includes sports activities, planned exercise, domestic activities, professional activities, and walks. The main objective of this review will be to describe all new diagnostic and therapeutic features of primary cutaneous ALCL regarding elderly patients and to evaluate the importance of physical activity.

\section{Clinical Presentation}

For most patients, the disease begins with a single skin nodular lesion (Figure 1), often ulcerated, with a diameter of more than $2 \mathrm{~cm}$, while for $20 \%$ of patients, the onset is multiple localizations on different skin areas (Figure 2). The clinical features of skin lesions are nodules, papules, plaques, and cellulitis-like ulcerations. Their color ranges from red to violaceous and may rapidly grow and have predilection for the head, neck, and extremities. Generally, the disease is asymptomatic and fevers, night sweats, or weight loss are usually lacking. Spontaneous regressions have been reported for $10 \%-42 \%$ of lesions. PcALCL may be the result of mycosis fungoides (MF) progression [20]. 
Therefore, in patients with pcALCL, a current or previous diagnosis of MF should be excluded. The differential diagnosis between pcALCL and CD30+ MF transformed can be even more difficult when there is a clinical presentation with a previous or simultaneous patch-plaque MF stage. The presence of multiple lesions in $20 \%$ of the cases can make the differential diagnosis difficult with the type C Lymphomatoid papulosis (LyP), which presents borderline lesions [20,21]. The onset with multiple sites and major extension appears to have a worse prognosis due to a higher incidence of cases with evolution to secondary cutaneous ALCL (scALCL). The International Society of the Cutaneous Lymphomas European Organization for Research and Treatment of Cancer proposed the tumor, node, metastases (TNM) classification of cutaneous lymphoma other than mycosis fungoides and Sezary syndrome (Table 1) [20]. This classification is based on the size of the lesions, the skin areas involved, the lymph node stations involved, and the extranodal and visceral localizations. It is clearly usable for the staging of both pcALCL and scALCL. Staging is essential to distinguish the pcALCL from scALCL (Table 1). All patients at diagnosis should perform a complete metabolic panel, lactate dehydrogenase (LDH), and Tc-PET, since these exams allow for the exclusion of a systemic infiltration from ALCL.

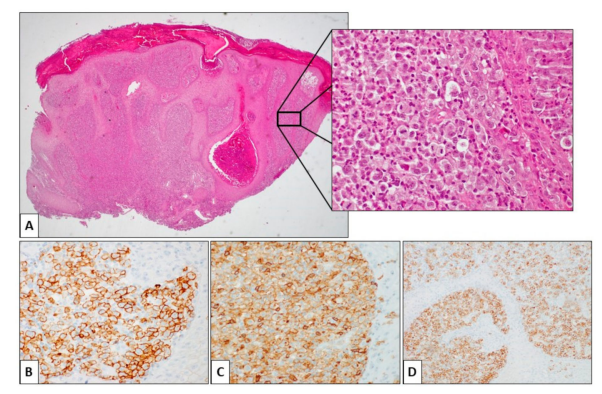

Figure 1. Histological features of primary cutaneous anaplastic large cell lymphoma (pcALCL). (A) This skin punch biopsy is characterized by a dense lymphoid population filling the dermis, without significant epidermotropism. The epidermis shows secondary changes, including hyperkeratosis and papillomatosis (Hematoxylin and eosin (H\&E), 2.4×). Inset: the neoplastic population is composed of large-sized cells with abundant, slightly eosinophilic cytoplasm and roundish, atypical nuclei. Two mitotic figures are evident in the center of the field. Some neutrophils and eosinophils are scattered in the context of the neoplastic population (H\&E, 20×). The large cells are positive for CD3 (B), CD4 (C), and CD30 (D) immunohistochemical staining.

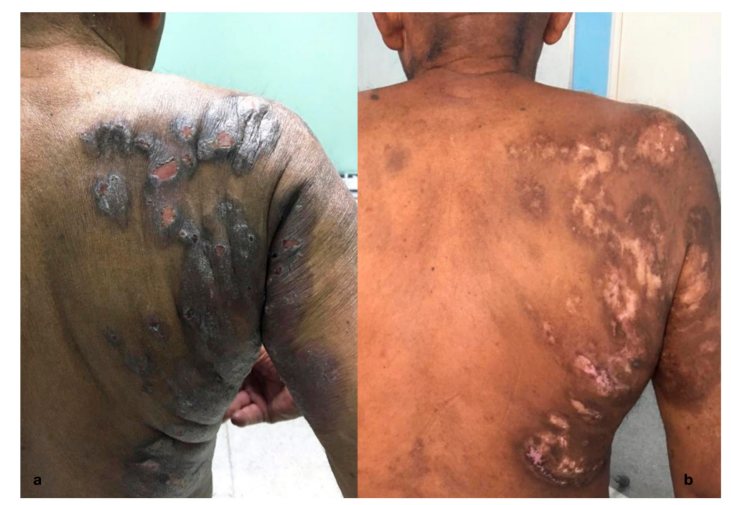

Figure 2. Clinical presentation of ALK- pcALCL with extensive ulcerated plaques located on the trunk and upper arms (a). Resolution of skin lesions, with central scarring and depigmentation after treatment (b). 
Table 1. International Society for Cutaneous Lymphomas (ISCL)/European Organization of Research and Treatment of Cancer (EORTC) tumor, node, metastases (TNM) classification of cutaneous lymphomas other than mycosis fungoides (MF)/Sézary syndrome (SS).

\begin{tabular}{|c|c|c|c|}
\hline Skin $(\mathrm{T})$ & T1 & & Solitary Skin Involvement \\
\hline & & T1a & Solitary lesion $<5 \mathrm{~cm}$ in diameter \\
\hline & & T1b & Solitary lesion $\geq 5 \mathrm{~cm}$ in diameter \\
\hline \multirow{4}{*}{\multicolumn{2}{|c|}{ T2 }} & & $\begin{array}{c}\text { Regional skin involvement: multiple lesions limited to one body } \\
\text { region or two contiguous body regions }\end{array}$ \\
\hline & & $\mathbf{T} 2 \mathbf{a}$ & All disease encompassing a $<15 \mathrm{~cm}$ diameter circular area \\
\hline & & $\mathbf{T} 2 \mathrm{~b}$ & All disease encompassing a 15 to $\leq 30 \mathrm{~cm}$ diameter circular area \\
\hline & & $\mathrm{T} 2 \mathrm{c}$ & All disease encompassing a $\geq 30 \mathrm{~cm}$ diameter circular area \\
\hline & T3 & & Generalized skin involvement \\
\hline & & T3a & Multiple lesions involving two noncontiguous body regions \\
\hline & & T3b & Multiple lesions involving $\geq 3$ body regions \\
\hline $\begin{array}{l}\text { Lymph } \\
\text { nodes (N) }\end{array}$ & No & & No clinical or pathologic lymph node involvement \\
\hline & N1 & & $\begin{array}{l}\text { Involvement of one peripheral or central lymph node region that } \\
\text { drains in an area of current or prior skin involvement }\end{array}$ \\
\hline & $\mathbf{N} 2$ & & $\begin{array}{c}\text { Involvement of } \geq 2 \text { peripheral or central lymph node regions or } \\
\text { involvement of any lymph node region that does not drain in an } \\
\text { area of current or prior skin involvement }\end{array}$ \\
\hline & N3 & & Involvement of central lymph nodes \\
\hline \multirow[t]{2}{*}{$\begin{array}{l}\text { Viscera } \\
\text { (M) }\end{array}$} & M0 & & No evidence of extracutaneous non-lymph node disease \\
\hline & M1 & & Extracutaneous non-lymph node disease present \\
\hline
\end{tabular}

Adapted from Kim YH, Willemze R, Pimpinelli N, et al. TNM classification system for primary cutaneous lymphomas other than mycosis fungoides and Sézary syndrome: a proposal of the International Society for Cutaneous Lymphomas (ISCL) and the Cutaneous Lymphoma Task Force of the European Organization of Research and Treatment of Cancer (EORTC). Blood 2007;110(2):480. [21].

\subsection{Histological and Molecular Features}

The classical form of pcALCL is characterized by a nodular infiltrate of large lymphoid cells, mostly confined to the dermis, and usually without epidermotropism (Figure 3). However, several histological variants have been described as rich in neutrophils and eosinophils (scattered in the classical form), which are more common in immunosuppressed patients: the angiocentric form, the angiodestructive form, the subcutaneous and keratoacanthoma-like form, the sarcomatoid variants with prevalent spindle-cell morphology, the small cells, and the intravascular ALCL form. The cell phenotype is usually characterized by a positivity for CD30 (75\% in tumor cells), CD3, CD4, CD45RO, and no expression for CD5 and CD2. In about $50 \%$ of cases, it has been described as positivity for CD71, HLA-DR and CD25 (IL-2R), TIA1, perforin, and granzyme B for the cutaneous lymphocyte antigen (CLA, HECA-452). Positive Epithelial Membrane Antigen (EMA) is only focal, unlike the systemic ALK- ALCL, which strongly expresses this marker. KIR3DL2 (CD158k) from neoplastic cells is expressed as in Sezary syndrome. Another important feature that is very useful for diagnostics is the alteration of the receptor complex of $\mathrm{T} / \mathrm{CD} 3$ cells and the transcription factors associated with $\mathrm{T}$ receptors and signal transduction molecules-a frequent finding in CD30+, systemic, and cutaneous lymphoproliferative diseases. The monoclonal rearrangement of the TCR gene is present in $65 \%-90 \%$ of cases. The majority of pcALCLs are ALK-, DUSP22-, and TP63-. However, other mutations may also occur, particularly considering the frequency order: DUSP22 rearrangement, ALK translocations, TP63 rearrangements, and NPM1-TYK2 gene fusion [22,23]. The DUSP22 rearrangements are related to a 
particular histological pattern characterized by the simultaneous presence of two different clones: one large CD30+ cell infiltrating the dermis, and another characterized by small CD30+ lymphoid cells with a pattern of pagetoid reticulosis. It has been shown that the expression of the chemokine receptor gene CCR8 is associated with DUSP22 rearrangements in ALCL. It is possible that the higher expression level of this receptor will explain the lower tendency of pcALCL to disseminate in extracutaneous sites contained by the limiting action of the immune system. The presence or absence of the DUSP22 rearrangement does not change the prognosis. In contrast to systemic anaplastic large-cell lymphoma (sALCL), the cases of ALK+ pcALCL seem to have a favorable outcome, comparable to that of patients with ALK- pcALCL. The TP63 rearrangement has long been studied because it has previously been associated with very aggressive cases of the disease. Subsequent studies do not seem to have confirmed the specificity of this rearrangement in the rapidly evolving forms. Other mutations seem to have a relationship with the evolution of the disease, including those on the path JAK1/STAT3. These mutations were found in only $5 \%$ of pcALCL. It is well known that deregulation of Notch signaling in hematopoietic cells is linked to the development of various hematological malignancies, including chronic B-cell lymphocytic leukemia, acute T-cell lymphoblastic leukemia, acute myeloid leukemia, multiple myeloma, sALCL, and Hodgkin's lymphoma. In addition, the pcALCL neoplastic cells have an increased expression of the intracellular domains of Notch1, Notch2, Notch3, and Notch4 receptors, as well as of the HES1 product and the Delta ligand. The inhibition of gamma-secretase with specific inhibitors has been shown to induce apoptosis and decrease cell viability in the pcALCL cell lines, inhibiting the Notch pathway. Therefore, this is a potential target to be considered in the near future for the therapies of these diseases.

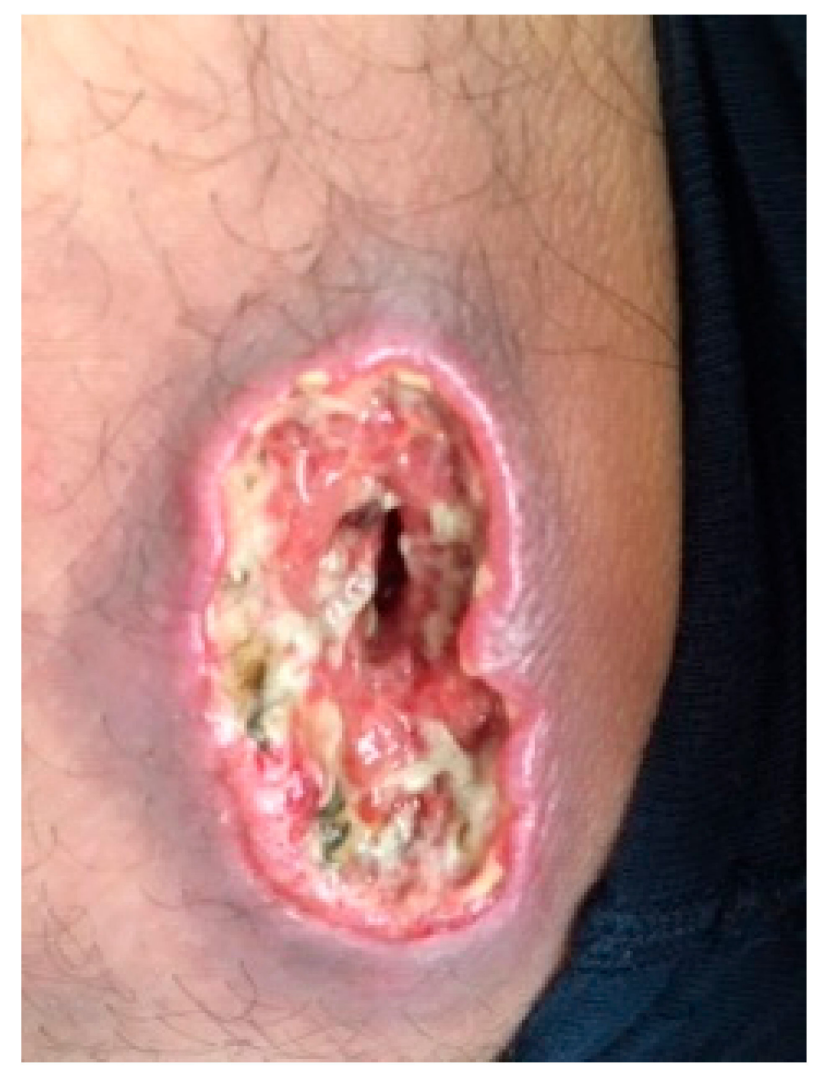

Figure 3. ALK- pcALCL single localization on a leg.

\subsection{Cytogenetic Alterations}

The following chromosomal alterations are characteristic of and recurrent in this type of lymphoma: the gains of 7q31 and losses in the 6q16-6q21, 6q27, and 13q34 regions. 


\section{Differential Diagnosis}

The most important differential diagnosis for a pcALCL is with the sALCL. Indeed, what appears to be an apparently isolated skin involvement may also be a skin localization of systemic disease. Consequently, the first step for a definitive diagnosis of pcALCL is the exclusion of sALCL. The morphology and immunophenotypic characteristics of LyP (in particular type C) and pcALCL overlap significantly and no biomarker has to date been able to reliably distinguish these two entities, so it is essential to correlate the pathological results with the clinical history that represents the only distinctive elements. In fact, it is the clinical behavior of LyP, characterized by recurrent episodes and the onset of papules and nodules sometimes at spontaneous resolution, which helps in the distinction between the two pathologies. Another very similar pathology for clinical presentation is MF with large cell transformation (MF-LCT), among other things, such as CD30+. From a histopathological point of view, MF-LCT is characterized by epidermotropic or dermal aggregates of CD30+ tumor cells that occur less frequently in pcALCL. The expression of GATA3+ is more frequent in MF-LCT, while the perforin is more expressed in pcALCL. Adult T-cell lymphoma (ATCL) may show diffuse CD30 expression and nuclear pleomorphism similar to pcALCL, but the presence of HTLV-1 in the former is pathognomonic. Other entities that enable the differential diagnosis of pcALCL include B-cell lymphoma and cutaneous leukemia. Some cases of diffuse large cell B-lymphoma CD30+ of an anaplastic variant may represent a diagnostic challenge, especially if CD20 and CD79a are negative. Classical syncytial nodular sclerosis Hodgkin's lymphoma (NSCHL) is another disease to consider, although pcALCL can rarely express CD30 and CD15 simultaneously, and CD45 is positive in most pcALCL and negative in NSCHL. Leukemia cutis may also show a pcALCL-like histology but usually expresses TdT, CD34, and/or CD117, and myeloid lineage markers such as myeloperoxidase.

\section{Therapies}

Complete surgical excision and local radiotherapy are the first line gold standard therapies of pcALCL with solitary or grouped localized lesions (up to T2N0M0) [24]. In the more advanced stages of the illness, with cutaneous dissemination and in the relapsing/refractory disease, the administration of brentuximab vedotin (BV), an anti-CD30 antibody-conjugate, has shown low toxicity and a high percentage of remissions and has been recommendable in the elderly patient $[25,26]$. Methotrexate and bexarotene are further indicated therapeutic options [27-29]. Appropriate screening for Hepatitis $\mathrm{C}$ virus (HCV) and Hepatitis B virus (HBV) infection should be performed to prevent any flare-ups of viral hepatopathies [30-34]. The $\gamma$-secretase inhibitors (inhibition of the Notch pathway) and the JAK $1 / 2 / 3$ inhibitors that are effective in vitro to control the cell growth of the pcALCL have also been suggested for the more advanced stages of the illness [29,34]. Other proposed treatments are the anti-ALK molecules, such as crizotinib, alectinib, and ceritinib, which in pcALCL patients with ALK rearrangements could downregulate the STAT3 pathway, inducing apoptosis. The IPH4102, a humanized monoclonal antibody directed against the KIR3DL2 cell receptor (CD158K), has also been proposed. Finally, histone deacetylase (HDAC) inhibitors (romidepsin and vorinostat) and demethylating agents have demonstrated efficacy in inducing cell cycle arrest, differentiation, and/or apoptosis of tumor cells [35-38].

\section{Discussion}

PCALCL is a lymphoma with a good prognosis and low mortality, which mainly concerns the elderly. Unfortunately, several patients have had multiple relapses throughout their clinical history, particularly in forms with diffuse skin localization in multiple body districts [39]. Many therapeutic lines, therefore, characterize the history of these patients. The chemotherapy protocols used for this subset of patients are variable. Cyclophosphamide, doxorubicin, vincristine, and prednisone (CHOP) is one of the most widely used protocols and has an overall response rate (ORR) of $85 \%$. Other regimens well-tolerated by the elderly with comorbidities are cyclophosphamide, vincristine, and prednisone 
(CVP) oral etoposide, gemcitabine, and methotrexate in low doses or in monotherapy [40,41]. All these regimens are valid therapeutic options in this subset of patients, although they have shown a high frequency of relapses. The efficacy of BV that has a $75 \%$ ORR seems different, with a fast response and good tolerability even in older patients. The most common adverse effect described is peripheral sensory neuropathy. The diagnosis of pcALCL is particularly difficult because its clinical presentation is variable. In addition, its histological and molecular characteristics show numerous affinities with similar lymphoproliferative pathologies where the prognosis and therapies are completely different. For this reason, it is important to study the patient from an anamnestic and clinical point of view to arrive at a correct diagnosis assisted by all available molecular, genetic, and histological investigations. The therapy should also consider eventual comorbidities and physical activity.

\section{Conclusions}

A physical activity program should be recommended to elderly patients with the aim to generate positive feelings and optimism and consider the disease as a moment of transition to face and overcome. It is not easy for those patients who already suffer from comorbidities [39-42], but it helps to keep the musculoskeletal and circulatory system in good functional condition, to eliminate excess body fat, and to stimulate the regulatory function of the immune system on macrophages, NK cells, cytokine production, and other factors involved in cancer prevention.

In addition, movement improves energy and hormone metabolism, reduces inflammation, and, finally, helps the patient to stay in good shape with improved self-esteem [42]. Most failures due to discontinuation of chemotherapy or reduction of the standard dosage are generally caused by clinical complications in patients undergoing treatment or by reduced performance status. Improved QoL and cardiovascular status predispose the patient to fully cope with the necessary chemotherapy protocol and, consequently, the likelihood of a successful outcome is increased [43-48]. There is no clear evidence of a direct relationship between physical activity and remission in pcALCL, but it is certainly an excellent support for specific treatments of this oncological pathology and all other indolent neoplasms in elderly patients [43-48].

The improvement in the general condition of the patients has a significant impact on the therapeutic program and, consequently, can favorably affect the prognosis.

Author Contributions: Conceptualization, A.S., P.V., A.R., and C.S.; data curation and investigation, B.C., A. C., G.C.N., T.T., R.F., G.A., and E.M.; methodology, A.S., P.V., A.R., E.S. and C.S.; project administration, A.S., P.V., A.R., and C.S.; writing - original draft, A.S., P.V., A.R., and C.S.; writing-review and editing, E.S. All authors have read and agreed to the published version of the manuscript.

Funding: This research received no external funding.

Conflicts of Interest: All the authors of the manuscript declare they have no conflicts of interest in connection with this paper.

\section{References}

1. Nikolaenko, L.; Zain, J.; Rosen, S.T.; Querfeld, C. CD30-Positive Lymphoproliferative Disorders. Cancer Treat Res. 2019, 176, 249-268. [PubMed]

2. Melchers, R.C.; Willemze, R.; Bekkenk, M.W.; de Haas, E.R.M.; Horvath, B.; van Rossum, M.M.; Sanders, C.J.G.; Veraart, J.C.J.M.; Vermeer, M.H.; Quint, K.D. In a multifunctional primary cutaneous anaplastic large cell lymphoma: Report of the Dutch Cutaneous Lymphoma Group. Br. J. Dermatol. 2018, 179, 724-731. [CrossRef] [PubMed]

3. Kaseb, H.; Rajasurya, V. Cancer, Anaplastic Large Cell Lymphoma (ALCL Ki 1+). Available online: https://www.ncbi.nlm.nih.gov/books/NBK537150/ (accessed on 12 August 2019).

4. Lynch, R.C.; Gratzinger, D.; Advani, R.H. Clinical Impact of the 2016 Update to the WHO Lymphoma Classification. Curr Treat Options Oncol. 2017, 18, 45. [CrossRef] [PubMed] 
5. Willemze, R.; Cerroni, L.; Kempf, W.; Berti, E.; Facchetti, F.; Swerdlow, S.H.; Jaffe, E.S. The 2018 update of the WHO-EORTC classification for primary cutaneous lymphomas. Blood 2019, 133, 1703-1714. [CrossRef] [PubMed]

6. Melton, L.; Brewer, B.; Kolva, E.; Joshi, T.; Bunch, M. Increasing access to care for young adults with cancer: Results of a quality-improvement project using a novel telemedicine approach to supportive group psychotherapy. Palliat. Support Care 2017, 15, 176-180. [CrossRef] [PubMed]

7. Fischetti, F.; Greco, G.; Cataldi, S.; Minoia, C.; Loseto, G.; Guarini, A. Effects of Physical Exercise Intervention on Psychological and Physical Fitness in Lymphoma Patients. Medicina 2019, 55, 379. [CrossRef] [PubMed]

8. Courneya, K.S.; Sellar, C.M.; Stevinson, C.; McNeely, M.L.; Peddle, C.J.; Friedenreich, C.M.; Tankel, K.; Basi, S.; Chua, N.; Mazurek, A.; et al. Randomized controlled trial of the effects of aerobic exercise on physical functioning and quality of life in lymphoma patients. J. Clin. Oncol. 2009, 27, 4605-4612. [CrossRef]

9. Lucía, A.; Earnest, C.; Pérez, M. Cancer-related fatigue: Can exercise physiology assist oncologists? Lancet Oncol. 2003, 4, 616-625. [CrossRef]

10. Dimeo, F.C. Effects of exercise on cancer-related fatigue. Cancer 2001, 92, 1689-1693. [CrossRef]

11. Oldervoll, L.M.; Kaasa, S.; Knobel, H.; Loge, J.H. Exercise reduces fatigue in chronic fatigued Hodgkins disease survivors-Results from a pilot study. Eur. J. Cancer 2003, 39, 57-63. [CrossRef]

12. Cramp, F.A.; Byron-Daniel, J.Z. Exercise for the management of cancer related fatigue in adults. Cochrane Database Syst. Rev. 2012, 11. [CrossRef] [PubMed]

13. Knols, R.; Aaronson, N.K.; Uebelhart, D.; Fransen, J.; Aufdemkampe, G. Physical exercise in cancer patients during and after medical treatment: A systematic review of randomized and controlled clinical trials. J. Clin. Oncol. 2005, 23, 3830-3842. [CrossRef] [PubMed]

14. Blair, C.K.; Morey, M.C.; Desmond, R.A.; Cohen, H.J.; Sloane, R.; Snyder, D.C.; Demark-Wahnefried, W. Light-intensity activity attenuates functional decline in older cancer survivors. Med. Sci. Sports Exerc. 2014, 46, 1375. [CrossRef] [PubMed]

15. Sica, A.; Vitiello, P.; Sorriento, A.; Ronchi, A.; Calogero, A.; Sagnelli, C.; Troiani, T.; Fasano, M.; Dodaro, C.A.; Franco, R.; et al. Lymphomatoid papulosis. Minerva Medica 2020. [CrossRef]

16. Craig, C.L.; Marshall, A.L.; Sjöström, M.; Bauman, A.E.; Booth, M.L.; Ainsworth, B.E.; Pratt, M.; Ekelund, U.; Yngve, A.; Sallis, J.F.; et al. International physical activity questionnaire: 12-country reliability and validity. Med. Sci. Sports Exerc. 2003, 35, 1381-1395. [CrossRef]

17. Minoia, C.; Ciavarella, S.; Lerario, G.; Daniele, A.; De Summa, S.; Napolitano, M.; Guarini, A. Improvable Lifestyle Factors in Lymphoma Survivors. Acta. Haematol. 2018, 139, 235-237. [CrossRef]

18. Global Recommendations on Physical Activity for Health. WHO Library Cataloguing-in-Publication Data 2010. Available online: https://www.who.int/dietphysicalactivity/global-PA-recs-2010.pdf (accessed on 25 December 2019).

19. Sica, A.; Casale, B.; Di Dato, M.T.; Calogero, A.; Spada, A.; Sagnelli, C.; Santagata, M.; Buonavolontà, P.; Fiorelli, A.; Salzano, A.; et al. Cancer and not cancer related chronic pain: From the physiopathological bases to the management. Open Med. 2019, 14, 761-766. [CrossRef]

20. Gerami, P.; Wickless, S.C.; Rosen, S.; Kuzel, T.M.; Ciurea, A.; Havey, J.; Guitart, J. Applying the new TNM classification system for primary cutaneous lymphomas other than mycosis fungoides and Sézary syndrome in primary cutaneous marginal zone lymphoma. J. Am. Acad. Dermatol. 2008, 59, 245-254. [CrossRef]

21. Kim, Y.H.; Willemze, R.; Pimpinelli, N.; Whittaker, S.; Olsen, E.A.; Ranki, A.; Dummer, R.; Hoppe, R.T.; ISCL and the EORTC. TNM classification system for primary cutaneous lymphomas other than mycosis fungoides and Sezary syndrome: A proposal of the International Society for Cutaneous Lymphomas (ISCL) and the Cutaneous Lymphoma Task Force of the European Organization of Research and Treatment of Cancer (EORTC). Blood 2007, 110, 479-484.

22. Caccavale, S.; Vitiello, P.; Franco, R.; Panarese, I.; Ronchi, A.; Sica, A.; Jurakic, T.R.; Alfano, R.; Argenziano, G. Dermoscopic characterization of folliculotropic mycosis fungoides selectively localized on trunk and limbs. Int. J. Dermatol. 2019, 58, e187-e189. [CrossRef]

23. Prieto-Torres, L.; Rodriguez-Pinilla, S.M.; Onaindia, A.; Ara, M.; Requena, L.; Piris, M.Á. CD30-positive primary cutaneous lymphoproliferative disorders: Molecular alterations and targeted therapies. Haematologica 2019, 104, 226-235. [CrossRef] [PubMed] 
24. Reginelli, A.; Belfiore, M.P.; Russo, A.; Turriziani, F.; Moscarella, E.; Troiani, T.; Brancaccio, G.; Ronchi, A.; Giunta, E.; Sica, A.; et al. A preliminary study for quantitative assessment with HFUS (High Frequency ultrasound) of nodular skin melanoma Breslow thickness in adults before surgery: Interdisciplinary team experience. Curr. Radiopharm. 2019. [CrossRef] [PubMed]

25. Duvic, M.; Tetzlaff, M.T.; Gangar, P.; Clos, A.L.; Sui, D.; Talpur, R. Results of a Phase II Trial of Brentuximab Vedotin for CD30+ Cutaneous T-Cell Lymphoma and Lymphomatoid Papulosis. J. Clin. Oncol. 2015, 33, 3759-3765. [CrossRef] [PubMed]

26. Prince, H.M.; Kim, Y.H.; Horwitz, S.M.; Dummer, R.; Scarisbrick, J.; Quaglino, P.; Zinzani, L.; Wolter, P.; Sanches, J.A.; Ortiz-Romero, P.L.; et al. Brentuximab vedotin or physician's choice in CD30-positive cutaneous T-cell lymphoma (ALCANZA): An international, open-label, randomised, phase 3, multicentre trial. Lancet 2017, 390, 555-566. [CrossRef]

27. Shinohara, M.M.; Shustov, A. How I treat primary cutaneous CD30+ lymphoproliferative disorders. Blood. 2019, 134, 515-524. [CrossRef]

28. Kempf, W.; Pfaltz, K.; Vermeer, M.H.; Cozzio, A.; Ortiz-Romero, P.L.; Bagot, M.; Olsen, E.; Kim, Y.H.; Dummer, R.; Pimpinelli, N.; et al. EORTC, ISCL, and USCLC consensus recommendations for the treatment of primary cutaneous CD30-positive lymphoproliferative disorders: Lymphomatoid papulosis and primary cutaneous anaplastic large-cell lymphoma. Blood 2011, 118, 4024-4035. [CrossRef]

29. Bekkenk, M.W.; Geelen, F.A.; van Voorst Vader, P.C.; Heule, F.; Geerts, M.L.; van Vloten, W.A.; Meijer, C.J.; Willemze, R. Primary and secondary cutaneous CD30(+) lymphoproliferative disorders: A report from the Dutch Cutaneous Lymphoma Group on the long-term follow-up data of 219 patients and guidelines for diagnosis and treatment. Blood 2000, 95, 3653-3661. [CrossRef]

30. Pisaturo, M.; Guastafierro, S.; Filippini, P.; Tonziello, G.; Sica, A.; Di Martino, F.; Sagnelli, C.; Ferrara, M.G.; Martini, S.; Cozzolino, D.; et al. Absence of occult HCV infection in patients experiencing an immunodepression condition. Infez. Med. 2013, 21, 296-301.

31. Tonziello, G.; Pisaturo, M.; Sica, A.; Ferrara, M.G.; Sagnelli, C.; Pasquale, G.; Sagnelli, E.; Guastafierro, S.; Coppola, N. Transient reactivation of occult hepatitis B virus infection despite lamivudine prophylaxis in a patient treated for non-Hodgkin lymphoma. Infection 2013, 41, 225-229. [CrossRef]

32. Coppola, N.; Pisaturo, M.; Guastafierro, S.; Tonziello, G.; Sica, A.; Iodice, V.; Sagnelli, C.; Ferrara, M.G.; Sagnelli, E. Increased hepatitis $C$ viral load and reactivation of liver disease in HCV RNA-positive patients with onco-haematological disease undergoing chemotherapy. Dig. Liver Dis. 2012, 44, 49-54. [CrossRef]

33. Coppola, N.; Pisaturo, M.; Guastafierro, S.; Tonziello, G.; Sica, A.; Sagnelli, C.; Ferrara, M.G.; Sagnelli, E. Absence of occult hepatitis $C$ virus infection in patients under immunosupressive therapy for oncohematological diseases. Hepatology 2011, 54, 1487-1489. [CrossRef] [PubMed]

34. Merli, M.; Frigeni, M.; Alric, L.; Visco, C.; Besson, C.; Mannelli, L.; Di Rocco, A.; Ferrari, A.; Farina, L.; Pirisi, M.; et al. Direct-Acting Antivirals in Hepatitis C Virus-Associated Diffuse Large B-cell Lymphomas. Oncologist 2018, 24, e720-e729. [CrossRef] [PubMed]

35. Matutes, E. The 2017 WHO update on mature T- and natural killer (NK) cell neoplasms. Int. J. Lab. Hematol. 2018, 40 Suppl 1, 97-103. [CrossRef]

36. Woo, D.K.; Jones, C.R.; Vanoli-Storz, M.N.; Kohler, S.; Reddy, S.; Advani, R.; Hoppe, R.T.; Kim, Y.H. Prognostic factors in primary cutaneous anaplastic large cell lymphoma: Characterization of clinical subset with worse outcome. JAMA Dermatol. 2009, 145, 667-674. [CrossRef] [PubMed]

37. Welborn, M.; Duvic, M. Antibody-Based Therapies for Cutaneous T-Cell Lymphoma. Am. J. Clin. Dermatol. 2019, 20, 115-122. [CrossRef]

38. Fujita, H.; Nagatani, T.; Miyazawa, M.; Wada, H.; Koiwa, K.; Komatsu, H.; Ikezawa, Z. Primary cutaneous anaplastic large cell lymphoma successfully treated with low-dose oral methotrexate. Eur. J. Dermatol. 2008, 18, 360-361.

39. Yamane, N.; Kato, N.; Nishimura, M.; Ito, M.; Yanagi, T.; Osawa, R. Primary cutaneous CD30+ anaplastic large-cell lymphoma with generalized skin involvement and involvement of one peripheral lymph node, successfully treated with low-dose oral etoposide. Clin. Exp. Dermatol. 2009, 34, e56-e59. [CrossRef]

40. Lee, W.J.; Moon, I.J.; Lee, S.H.; Won, C.H.; Chang, S.E.; Choi, J.H.; Moon, K.C.; Park, C.S.; Huh, J.; Lee, M.W. Cutaneous anaplastic large-cell lymphoma (ALCL): A comparative clinical feature and survival outcome analysis. J. Am. Acad. Dermatol. 2016, 74, 1135-1143. [CrossRef] 
41. Martino, M.; Ciavarella, S.; De Summa, S.; Russo, L.; Meliambro, N.; Imbalzano, L.; Gallo, G.A.; Moscato, T.; Messina, G.; Ferreri, A.; et al. A Comparative Assessment of Quality of Life in Patients with Multiple Myeloma Undergoing Autologous Stem Cell Transplantation Through an Outpatient and Inpatient Model. Biol. Blood Marrow Transplant. 2018, 24, 608-613. [CrossRef]

42. Calogero, A.; Sagnelli, C.; Carlomagno, N.; Tammaro, V.; Candida, M.; Vernillo, A.; Peluso, G.; Minieri, G.; Santangelo, M.; Dodaro, C.A.; et al. Familial polyposis coli: The management of desmoid tumor bleeding. Open Med. 2019, 14, 572-576. [CrossRef]

43. Ciavarella, S.; Minoia, C.; Quinto, A.M.; Oliva, S.; Carbonara, S.; Cormio, C.; Cox, M.C.; Bravo, E.; Santoro, F.; Napolitano, M.; et al. Improving Provision of Care for Long-term Survivors of Lymphoma. Clin. Lymphoma Myeloma Leuk. 2017, 17, e1-e9. [CrossRef] [PubMed]

44. Gerritson, J.K.W.; Vincent, A.J.P.E. Exercise improves quality of life in patients with cancer: A systematic review and meta-analysis of randomized controlled trials. Br. J. Sports Med. 2016, 50, 796-803. [CrossRef] [PubMed]

45. Duncan, M.; Moschopoulou, E.; Herrington, E.; Deane, J.; Roylance, R.; Jones, L.; Bourke, L.; Morgan, A.; Chalder, T.; Thaha, M.A.; et al. Review of systematic reviews of non-pharmacological interventions to improve quality of life in cancer survivors. BMJ Open 2017, 7, e015860. [CrossRef] [PubMed]

46. Lymphoma Action. 2019. Available online: https://lymphoma-action.org.uk/ (accessed on 25 December 2019).

47. Parás-Bravo, P.; Salvadores-Fuentes, P.; Alonso-Blanco, C.; Paz-Zulueta, M.; Santibañez-Margüello, M.; Palacios-Ceña, D.; Boixadera-Planas, E.; Fernández-de-las-Peñas, C. The impact of muscle relaxation techniques on the quality of life of cancer patients, as measured by the FACT-G questionnaire. PLoS ONE 2017, 12, e0184147. [CrossRef] [PubMed]

48. Reich, R.R.; Lengacher, C.A.; Alinat, C.B.; Kip, K.E.; Paterson, C.; Ramesar, S.; Han, H.S.; Ismail-Khan, R.; Johnson-Mallard, V.; Moscoso, M.; et al. Mindulness-based stress reduction in post-treatment breast cancer patients: Immediate and sustained effects across multiple symptom clusters. J. Pain Symptom Manag. 2017, 53, 85-95. [CrossRef] [PubMed]

(C) 2020 by the authors. Licensee MDPI, Basel, Switzerland. This article is an open access article distributed under the terms and conditions of the Creative Commons Attribution (CC BY) license (http://creativecommons.org/licenses/by/4.0/). 